\title{
Pemodelan Ontologi Rekam Medis dengan Pendekatan Landasan Hukum Rekam Medis dan Relational Database
}

\author{
Maksum Ro'is Adin Saf \\ Program Studi Teknik Informatika, Jurusan Teknologi Informasi, Politeknik Caltex Riau \\ maksum@pcr.ac.id
}

\begin{abstract}
Medical Record is one of confidential file that has a definite legal basis included in its management. Nowdays electronic medical record was developed rapidly, but the implementation of the legal basis for medical records in the information system has not been carried out properly. Furthermore, the conceptualization of the legal basis of medical records into the ontology model produces a model that is not easily translated into a medical record management information system design. Medical records conceptualized and visualization by combining the ontology development method with relational database model approach was done in this research, in order to produce an ontology model that can fulfil all of the medical records legal aspects and thus, easy to use as the basis of the development of the medical records information system management. This study uses the Architecture Analysis method of Tradeoff Method to create a relational database model and then converted into an ontology with the RTAXON method. The results of this research are medical record ontology models that meet the legal requirements and have ease of implementation in the information system. Based on the OntoQA method on the results of the ontology modeling has value of Relationship Richness $(R R)=0.78$, this ontology is information rich or diverse and has more non-inheritance relations. Value of Attribute Richness $(A R)=6.6$, this ontology has a lot of information with an average of each class having 6 attributes. The value of Inheritance Richness $(I R)=4.5$, this ontology has general knowledge, when compared with the previous ontology there is between PSM and SWETO.
\end{abstract}

Keywords: Medical Record Ontology, OntoQA, Relational Database, RDBToOnto

\begin{abstract}
ABSTRAK
Rekam Medis merupakan bagian dari berkas khusus yang memiliki landasan hukum pasti dalam pengelolaanya oleh instansi yang diizinkan. Pesatnya perkembangan teknologi informasi membuat pengembangan sistem informasi pengelolaan rekam medis banyak dilakukan oleh berbagai pihak, akan tetapi implementasi landasan hukum rekam medis ke dalam sistem informasi tersebut belum dilakukan secara baik. Di lain sisi konseptualisasi landasan hukum rekam medis ke dalam model ontologi menghasilkan model yang tidak mudah diterjemahkan ke dalam sebuah rancangan sistem informasi pengelolaan rekam medis. Pada penelitian ini dilakukan proses konseptualisasi dan visualisasi rekam medis dengan menggabungkan metode pengembangan ontologi dengan pendekatan model database relasional untuk menghasilkan sebuah model ontologi yang memenuhi seluruh aspek landasan hukum rekam medis dan juga mudah digunakan untuk pengembangan sistem informasi pengelolaan rekam medis. Penelitian ini menggunakan metode Architecture Tradeoff Analysis Method untuk menghasilkan rancangan Database Relational yang kemudian dikonversikan menjadi ontologi dengan metode RTAXON. Hasil dari peneltian ini adalah sebuah model ontologi rekam medis yang memenuhi kepatuhan terhadap aturan perundangan dan memiliki kemudahan untuk diimplementasikan ke dalam sistem informasi. Berdasarkan pengujian dengan metode OntoQA pada hasil pemodelan ontologi yang dibuat, diperoleh nilai Relationship Richness $(R R)=0,78$, yang artinya ontologi ini bersifat kaya informasi atau berragam dan lebih banyak relasi non-inheritance.Dannilai Attribute Richness $(A R)=6,6$, yang artinya ontologi ini memiliki informasi yang banyak dengan rata-rata setiap class memiliki 6 attribute. Adapun nilai Inhertitance Richness $(I R)=4,5$, yang artinya ontologi ini memiliki pengetahuan yang umum, jika dibandingkan dengan ontologi terdahulu ada diantara PSM dan SWETO.
\end{abstract}

Kata kunci: Ontologi Rekam Medis, RTAXON, RDBToOnto, Database Relational 


\section{PENDAHULUAN}

Rekam medis merupakan salah satu dokumen hukum yang bersifat rahasia dan diatur dengan jelas dalam peraturan perundangan di Indonesia[1], pengaturan rekam medis dalam aturan perundangan sangat lengkap mulai dari pembuatan, pengisian, perawatan hingga pemusnahan dokumen[2]. Rekam medis adalah berkas yang berisi catatan dan dokumen antara lain identitas pasien, hasil pemeriksaan, pengobatan yang telah diberikan, serta tindakan dan pelayanan lain yang telah diberikan kepada pasien[3]. Seiring perkembangan teknologi informasi yang semakin pesat, sistem informasi pengelolaan rekam medis atau rekam medis elektronik banyak dikembangkan oleh berbagai pihak[4], salah satu hal yang harus menjadi acuan pihak yang mengembangkan sistem informasi pengelolaan rekam medis tersebut adalah kepatuhan terhadap landasan hukum rekam medis tersebut.

Sistem informasi dikembangkan berdasarkan kebutuhan pengguna, seorang sistem analis akan menterjemahkan kebutuhan pengguna ke dalam sebuah rancangan sistem termasuk di dalamnya perancangan database. Database menjadi salah satu hal yang sangat diperhatikan karena akan mempengaruhi sebuah sistem informasi, maka pemilihan model database yang sesuai akan menjadi salah satu kunci kualitas sebuah sistem informasi[5]. Salah satu model database yang populer digunakan adalah relational database.

Ontologi merupakan bagian dari artificial inteligence yang mengambil konsep dari ilmu filsafat. Dalam ontologi setiap data yang ada diberikan makna yang sesuai dan kemudian dibentuk keterkaitan antar obyek yang ada pada suatu domain tertentu sehingga data tersebut menjadi sebuah data yang memiliki makna yang lengkap[6]. Ontologi banyak digunakan untuk membangun sebuah konsep basis pengetahuan pada suatu domain tertentu untuk kemudian digunakan dalam semantic system, keberadaan basis pengetahuan yang lengkap pada sebuah semantic system menjadikan sistem tersebut memiliki kecerdasan buatan[7].

Ontologi rekam medis berdasarkan landasan hukum yang berlaku di Indonesia sudah dikembangkan dengan menggunakan metode Methontology, konsep yang digunakan pada ontologi ini sepenuhnya merujuk pada aturan perundangan seputar rekam medis yang berlaku di Indonesia[8]. Berdasarkan hasil pengujian dan analisis menggunakan metode Ontology Quality Analysis (OntoQA) ditemukan bahwa ontologi rekam medis tersebut masih sangat sederhana berdasarkan pada hasil perhitungan Relationship Richness (RR), Inheritance Richness (IR), dan Attribute Richness (AR) yang dihasilkan. OntoQA merupakan salah satu metode pengujian ontologi yang banyak digunakan untuk mengukur kualitas sebuah ontologi[9]. Di sisi lain pengembangan yang dilakukan pada ontologi tersebut belum mempertimbangkan faktor implementasi konsep pengetahuan tersebut ke dalam sebuah semantic system untuk meningkatkan sistem informasi pengelolaan rekam medis berbasis relational database yang ada saat ini[10].

Kesenjangan yang terjadi antara perancangan ontologi rekam medis yang menekankan kepada aspek aturan perundangan dengan kemudahan implementasi sebuah ontologi rekam medis yang memiliki pendekatan relational database menjadi sebuah permasalahan yang harus diselesaikan. Pada penelitian ini, dilakukan pengembangan ontologi rekam medis dengan menggabungkan antara konsep pengetahuan yang diambil dari peraturan perundangan seputar rekam medis dan pendekatan proses pengembangan relational database untuk sistem informasi pengelolaan rekam medis. Luaran dari penelitian ini adalah sebuah ontologi rekam medis yang mudah untuk digunakan dalam sebuah sistem informasi pengelolaan rekam medis berbasis web semantic yang dipastikan telah menjalankan semua aturan perundangan seputar rekam medis yang berlaku. 
PETIR: Jurnal Pengkajian dan Penerapan Teknik Informatika

Vol. 13, No. 2, September 2020, P-ISSN 1978-9262, E-ISSN 2655-5018

DOI: https://doi.org/10.33322/petir.v13i2.988

\section{METODE PENELITIAN}

\subsection{Alur Penelitian}

Pada penelitian ini dilakukan penggabungan metode perancangan model database dan metode pengembangan ontologi. Proses perancangan model database menggunakan metode Architecture Tradeoff Analysis Method (ATAM) kemudian hasil luarannya berupa desain database relational dikonversikan menjadi sebuah ontologi rekam medis. Penggunaan metode ATAM untuk menterjemahkan aturan perundangan seputar rekam medis ke dalam desain relational database memastikan bahwa desain relational database yang dihasilkan mampu merepresentasikan penerapan landasan hukum rekam medis dalam sistem informasi pengelolaan rekam medis.

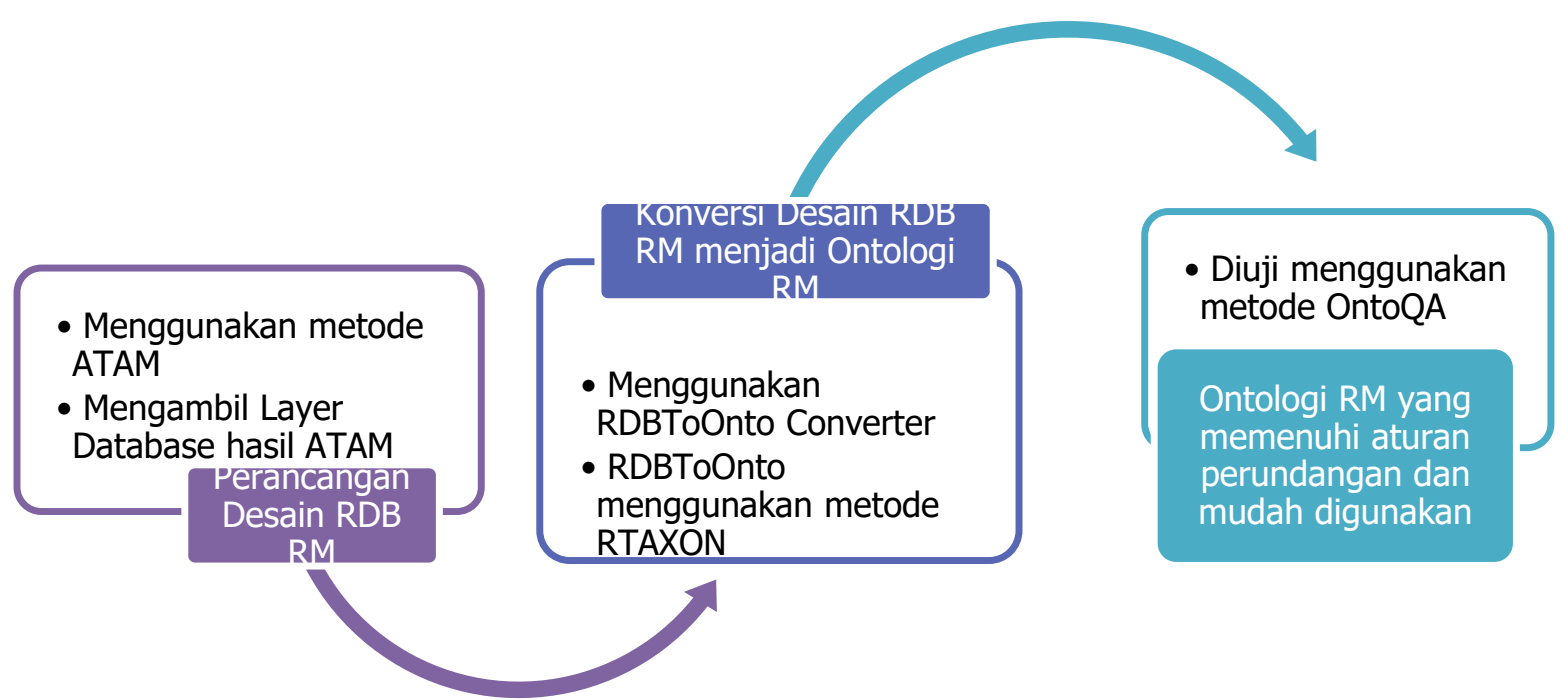

Gambar 1. Alur Penelitian

\subsection{Perancangan Desain Relational Database Rekam Medis}

Architecture Tradeoff Analysis Method (ATAM) memiliki 9 langkah yang terdiri dari 3 langkah awal atau presentation, 3 langkah investigasi dan analisis, dan 3 langkah testing[11]. Secara umum implementasi ATAM pada penelitian ini dapat dilihat pada Gambar 2.

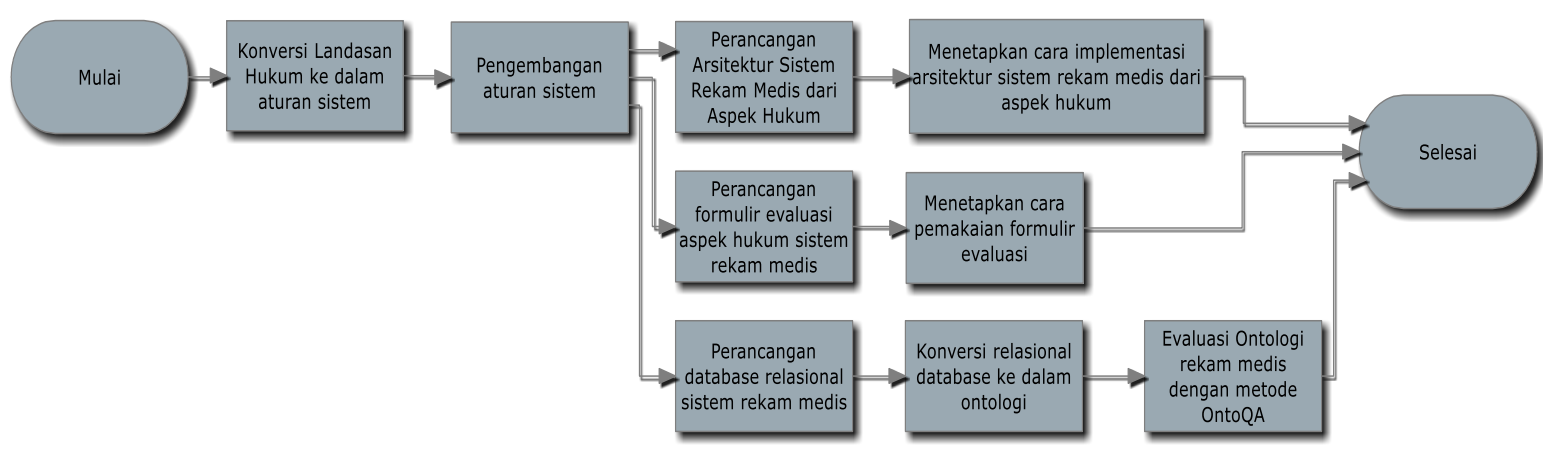

Gambar 2. Implementasi ATAM untuk merancang RDB RM

Adapun detail tahapan implementasi metode ATAM pada penelitian ini adalah sebagai berikut: 


\section{Bagian 1, Presentation.}

1. Memulai Proses ATAM

Proses penelitian dengan metode ATAM ini diawali dengan kajian pustaka dan berdiskusi dengan para ahli serta para praktisi dibidang rekam medis.

2. Mendeskripsikan Permasalahan yang ditemukan

Hasil dari diskusi dan pengkajian pustaka dilanjutkan dengan mengidentifikasi serta mendeskripsikan permasalahan yang dijumpai dilapangan.

3. Merancang Arsitektur berdasarkan permasalahan

Setelah ditentukan bahwa fokus utama penelitian ini adalah sisi landasan hukum rekam medis, maka dimulai proses perancangan arsitektur dengan menterjemahkan kandungan setiap ayat yang berhubungan dengan rekam medis.

\section{Bagian 2, Investigasi dan Analisa}

4. Pendeskripsian aturan sistem dan membuat pola penerapan aturan

Setelah tiap kandungan ayat diterjemahkan ke dalam aturan sistem, selanjutnya dilakukan klasifikasi aturan menurut sasaran implementasinya. Melengkapi pola penerapan arsitektur yang dirancang maka disusunlah sebuah formulir instrumen evaluasi rekam medis.

5. Membuat Quality Attribute Utility Tree

Quality Attribute Utility Tree dilakukan dengan membagi setiap aturan sistem yang diadopsi dari landasan hukum ke dalam pohon utilitas sistem yang ada pada metode ATAM.

6. Menganalisis Metode Penerapan berdasarkan hasil dari langkah 5

Metode penerapan yang terbaik untuk arsitektur sistem rekam medis dari sisi hukum adalah dengan mengevaluasi sistem yang ada saat ini dan mempersiapkan gambaran untuk masa depan, dalam hal ini untuk evaluasi saat ini dibuatlah sebuah formulir evaluasi sistem.

Adapun untuk gambaran masa depan digunakan metode konversi database menjadi ontologi, hal ini dianggap paling baik mengingat sudah banyaknya sistem rekam medis yang berjalan saat ini sehingga mengkonversi lebih baik daripada menggantikan yang ada,

\section{Bagian 3, Testing}

7. Berdiskusi untuk menentukan skenario terbaik

Pada penelitian ini, presentasi menentukan skenario terbaik dari hasil yang ada dilakukan dengan cara diskusi dengan pembimbing penelitian, dengan rekan-rekan penelitian, dan akan dipresentasikan pada ujian pra pendadaran dan ujian pendadaran.

8. Menganalisis metode penerapan berdasarkan hasil dari langkah 7

Dari hasil analisis diharapkan akan menghasilkan solusi untuk menentukan bentuk akhir dari arsitektur rekam medis berbasis landasan hukum ini.

9. Membuat arsitektur yang diperlukan.

Hasil akhir dari metode ATAM adalah dibentuknya arsitektur yang terbaik untuk diterapkan ke dalam sistem.

Dari arsitektur sistem rekam medis yang dihasilkan, pada penelitian ini fokus untuk mengimplementasikan layer database ke dalam desain database relational. Proses tersebut menghasilkan sebuah rancangan database relational seperti yang tambah pada Gambar 3. 


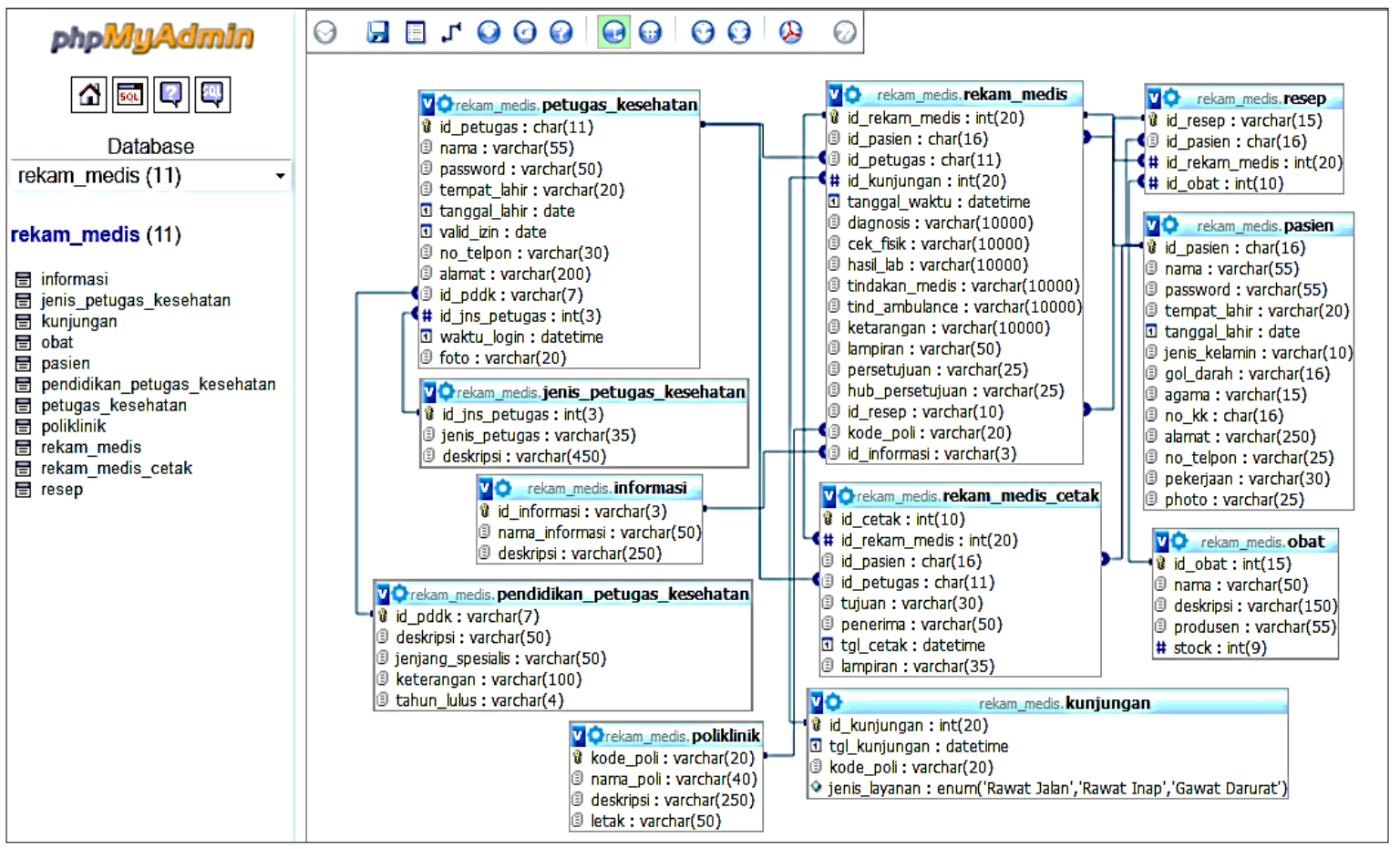

Gambar 3. Desain Relational Database Rekam Medis

\subsection{Pembentukan Ontologi Rekam Medis}

Pembentukan ontologi rekam medis dilakukan dengan melakukan konversi Desain Relational Database Rekam Medis pada Gambar 3 ke dalam ontologi. Hal ini dilakukan agar diperoleh ontologi rekam medis yang mudah diimplementasikan karena berorientasi kepada rancangan database yang banyak digunakan saat ini.

Proses konversi database relasional menjadi ontologi pada RDBToOnto menggunakan metode RTAXON. Metode RTAXON melakukan pemetaan pada dua bagian, yaitu: skema database dipetakan ke dalam skema ontologi, dan konten dari database dipetakan kedalam individual[12]. Lebih detail seperti yang tampak pada Tabel 1.

Tabel 1. Contoh Pemetaan yang dilakukan dengan metode RTAXON

\begin{tabular}{|c|c|c|c|c|c|}
\hline \multirow{2}{*}{ No } & \multicolumn{2}{|c|}{ Database Relasional } & \multicolumn{2}{|c|}{ Hasil Pada Ontologi } & \multirow[b]{2}{*}{ Keterangan } \\
\hline & $\begin{array}{c}\text { Nama } \\
\text { Elemen }\end{array}$ & Contoh & $\begin{array}{c}\text { Nama } \\
\text { Elemen }\end{array}$ & Contoh & \\
\hline 1 & Nama Tabel & Pasien & $\begin{array}{l}\text { Nama } \\
\text { Class }\end{array}$ & Class Pasien & \\
\hline 2 & $\begin{array}{l}\text { Nama } \\
\text { Kolom }\end{array}$ & Id_Pasien & $\begin{array}{l}\text { Data } \\
\text { Property }\end{array}$ & Id_Pasien & \\
\hline 3 & $\begin{array}{l}\text { Isi Kolom } \\
\text { Kategori }\end{array}$ & Jenis_Layanan & Sub-Class & $\begin{array}{l}\text { Rawat Inap, Rawat } \\
\text { Jalan, UGD, Bencana }\end{array}$ & $\begin{array}{l}\text { Data Pada } \\
\text { kolom menjadi } \\
\text { sub-class }\end{array}$ \\
\hline 4 & $\begin{array}{l}\text { Relasi antar } \\
\text { Tabel }\end{array}$ & $\begin{array}{l}\text { Id_pasien [PK:Pasien] } \\
\text {-Id_Pasien } \\
\text { [FK:Rekam_Medis] }\end{array}$ & $\begin{array}{l}\text { Object } \\
\text { Property }\end{array}$ & $\begin{array}{l}\text { rekam_medis has } \\
\text { id_pasien }\end{array}$ & \\
\hline 5 & $\begin{array}{l}\text { Data } \\
\text { (Konten } \\
\text { Database) } \\
\end{array}$ & $\begin{array}{l}\text { [Nama:Pasien] } \\
\text { Maksum Rois Adin Saf }\end{array}$ & Individual & $\begin{array}{l}\text { Pasien-nama } \\
\text { "Maksum Rois Adin } \\
\text { Saf" }\end{array}$ & \\
\hline
\end{tabular}


PETIR: Jurnal Pengkajian dan Penerapan Teknik Informatika

Vol. 13, No. 2, September 2020, P-ISSN 1978-9262, E-ISSN 2655-5018 DOI: https://doi.org/10.33322/petir.v13i2.988

\section{HASIL DAN PEMBAHASAN}

Hasil konversi dari Desain Relatioan Database Rekam Medis menjadi ontologi menghasilkan sebuah ontologi memiliki basis pengetahuan yang kompleks seperti terlihat pada Gambar 4 .

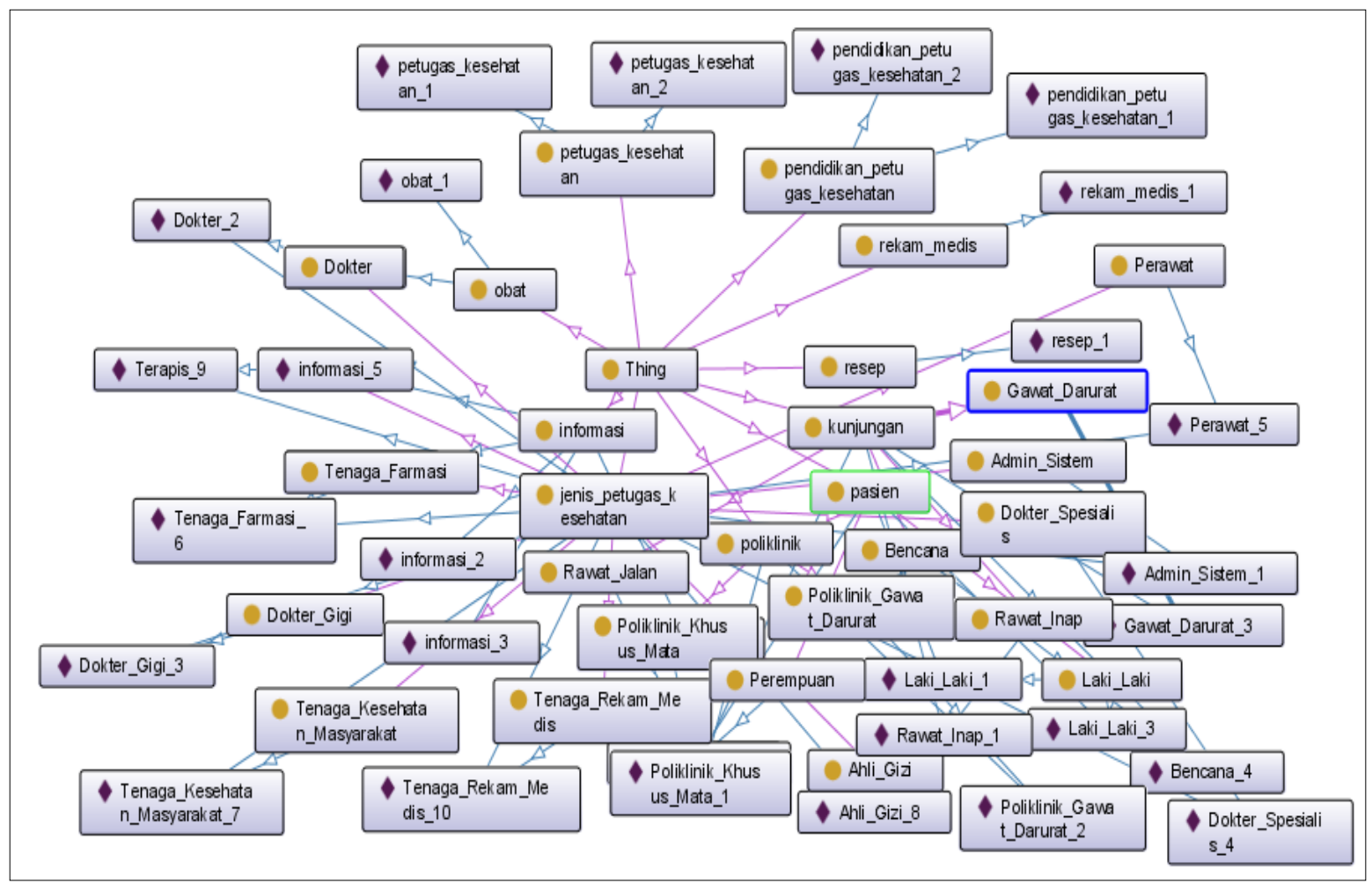

Gambar 4. Ontograf ontologi Rekam Medis

Ontologi Rekam Medis yang dihasilkan terdiri dari 515 axiom, 28 class, dan beberapa elemen lain seperti yang tampak pada Tabel 2.

Tabel 2. Ontology Metrics

\begin{tabular}{|r|l|c|}
\hline No & \multicolumn{1}{|c|}{ Ontology Element } & Count \\
\hline 1 & Axiom & 515 \\
\hline 2 & Logical axiom & 421 \\
\hline 3 & Class & 28 \\
\hline 4 & Data Property & 66 \\
\hline 5 & SubClassOf axioms & 18 \\
\hline 6 & Functional Data Property axioms & 66 \\
\hline 7 & Data Property Domain axioms & 66 \\
\hline 8 & Data Property Range axioms & 66 \\
\hline 9 & Class Assertion axioms & 51 \\
\hline 10 & Data Property Assertion axioms & 154 \\
\hline
\end{tabular}

Ontologi Rekam Medis diuji menggunakan metode Ontology Quality Analysis (OntoQA), metode ini dipilih karena dianggap tepat untuk mengetahui kualitas ontologi hasil dari konversi database rekam medis. OntoQA terdiri dari tiga rangkaian evaluasi yaitu: evaluasi relationship richness (RR), evaluasi inheritance richness (IR), dan evaluasi attribute Richness (AR). 
1. Evaluasi Relationship Richness (RR).

Relationship Richness (RR) atau yang disebut juga Relationship Diversity (RD)[13], digunakan untuk mengetahui keberagaman relasi yang dimiliki. RR didefinisikan dengan Persamaan (1).

$$
R R=\frac{|P|}{|H|+|P|}
$$

Jumlah relasi non-inheritance $(\mathrm{P})$ dibagi dengan total relasi yang ada (jumlah relasi inheritance $(\mathrm{H})$ ditambah jumlah relasi non-inheritance). Jika nilai $\mathrm{RR}$ yang didapatkan mendekati 0 maka sebagian besar dari relasi adalah inheritance. Sebaliknya, jika nilai RR semakin mendekati 1 maka semakin banyak relasi non-inheritance yang dimiliki. Ontologi yang didominasi oleh relasi inheritance biasanya memiliki informasi yang lebih sedikit dibanding ontologi yang didominasi oleh relasi non-inheritance[14]. Sebagai acuan penilaian bisa digunakan tabel klasifikasi seperti yang tampak pada Tabel 3 .

Tabel 3 Skala Klasifikasi Nilai RR

\begin{tabular}{|c|c|}
\hline Rentang Skala & Nilai Skala \\
\hline $0,00-0,20$ & Minimum \\
\hline $0,21-0,40$ & Kurang \\
\hline $0,41-0,60$ & Cukup \\
\hline $0,61-0,80$ & Kaya \\
\hline $0,80-1,00$ & Maksimum \\
\hline
\end{tabular}

Pada ontologi rekam medis ini terdapat 66 relasi non-inheritance dan 18 relasi inheritance. Dengan menggunakan persamaan (1) maka dihasilkan perhitungan sebagai berikut:

$\mathrm{RR}=\frac{66}{66+18}=0,78$

Dengan hasil $\mathrm{RR}=0,78$, Berdasarkan pada Tabel 3 Skala Klasifikasi nilai RR, maka pada ontologi rekam medis ini termasuk dalam kategori kaya informasi, hal ini terjadi karena lebih banyak terdapat relasi non-inheritance.

2. Evaluasi Inheritance Richness (IR).

Inheritance Richness (IR) atau yang disebut juga Schema Deepness (SD) digunakan untuk mengukur distribusi informasi dengan membedakan ontologi ke dalam 2 karakter, yaitu ontologi dengan karakter deep atau ontologi dengan karakter shallow. Ontologi yang memiliki banyak level inheritance merupakan ontologi yang bersifat deep. Artinya, ontologi tersebut memiliki representasi informasi yang lebih mendalam atau spesifik terhadap sebuah domain begitu juga sebaliknya[15]. Nilai IR didapatkan dari rata-rata jumlah subclass per class seperti yang tampak pada persamaan (2).

$$
\mathrm{IR}=\frac{|\mathrm{H}(\mathrm{c})|}{|\mathrm{C}|}
$$


PETIR: Jurnal Pengkajian dan Penerapan Teknik Informatika

Vol. 13, No. 2, September 2020, P-ISSN 1978-9262, E-ISSN 2655-5018 DOI: https://doi.org/10.33322/petir.v13i2.988

Sebagai acuan, Tatir memberikan tabel perbandingan yang berisikan nilai IR dari beberapa ontologi terdahulu seperti yang tampak pada Tabel 4 [16][17][18][19].

Tabel 4. Perbandingan Nilai IR Beberapa Ontologi

\begin{tabular}{|c|l|c|}
\hline No & \multicolumn{1}{|c|}{ Ontologi } & IR \\
\hline 1 & TAP (Guha \& McCool, 2003) & 5.36 \\
\hline 2 & PSM (Tan et al., 2012) & 4.59 \\
\hline 3 & SWETO (Aleman \& Halaschek, 2004) & 4.00 \\
\hline 4 & GlycO (Sheth \& York, 2004) & 1.56 \\
\hline
\end{tabular}

Selanjutnya dari beberapa nilai IR yang telah dikumpulkan dibuat rentang skor nilai IR dengan acuan nilai IR dari TAP dan dari GlycO, sehingga dihasilkan rentang skor seperti yang tampak pada Tabel 5 .

Tabel 5. Rentang Skor Nilai IR

\begin{tabular}{|c|c|}
\hline Rentang Skala & Nilai Skala \\
\hline $0,00-1,34$ & Spesifik \\
\hline $1,35-2,68$ & Cukup Spesifik \\
\hline $2,69-4,02$ & Cukup Umum \\
\hline $4,03-5,36$ & Umum \\
\hline
\end{tabular}

Pada ontologi rekam medis ini terdapat 4 class yang memiliki sub-class, dengan 18 total sub-class. Dengan merujuk kepada persamaan (2), dilakukan perhitungan sebagai berikut:

$\mathrm{IR}=\frac{18}{4}=4,5$

Dengan hasil IR $=4,5$ maka berdasarkan pada Tabel 5 Klasifikasi Nilai IR, maka ontologi ini termasuk kategori umum. Jika dibandingkan dengan ontologi terdahulu yang menjadi patokan pada Tabel 4, ontologi ini berada diantara PSM dan SWETO.

3. Evaluasi Attribute Richness (AR).

Attribute Richness (AR) dapat digunakan untuk mengukur jumlah informasi yang ada. Semakin banyak attribute atau slot maka semakin banyak informasi yang disediakan oleh ontologi. AR didefinisikan sebagai jumlah rata-rata attribute per class. AR didapatkan dengan membagi jumlah attribute untuk semua class (att) dengan jumlah class (C), sepert yang tampak pada persamaan (3).

$$
A R=\frac{|\mathrm{att}|}{|\mathrm{C}|}
$$

Pada ontologi rekam medis ini ditemukan 66attribute dan 10class.Dengan persamaan (3) dilakukan perhitungan sebagai berikut.

$$
\mathrm{AR}=\frac{66}{10}=6,6
$$


Dengan hasil $\mathrm{AR}=6$,6atau rata-rata 6 atribut per class-nya dimana atribut tersebut berisi data atau informasi dari class. Hasil tersebut menunjukkan jumlah informasi yang disediakanpada ontologi ini sangat banyak.

Kesimpulan dari evaluasi ontologi rekam medis dengan menggunakan metode OntoQA bahwa ontologi rekam medis yang dihasilkan dari konversi database menjadi ontologi yang cukup umum, dengan kedalaman pengetahuan yang memadai, dan banyak memiliki relasi non-inheritance.

Tabel 6. Hasil Uji dengan OntoQA

\begin{tabular}{|c|l|c|l|}
\hline No & \multicolumn{1}{|c|}{ Nama Evaluasi } & Hasil & \multicolumn{1}{c|}{ Kesimpulan } \\
\hline 1 & $\begin{array}{l}\text { Relationship Richness } \\
\text { (RR) }\end{array}$ & 0,78 & $\begin{array}{l}\text { Ontologi bersifat kaya informasi, didominasi oleh relasi } \\
\text { non-inheritance }\end{array}$ \\
\hline 2 & Inheritance Richness (IR) & 4,5 & Pengetahuan bersifat Umum, diantara PSM dan SWETO. \\
\hline 3 & Attribute Richness (AR) & 6,6 & $\begin{array}{l}\text { Rata rata setiap class memiliki 6 attribute, berarti memiliki } \\
\text { banyak informasi. }\end{array}$ \\
\hline
\end{tabular}

\section{.4. KESIMPULAN DAN SARAN}

Hasil dari penelitian ini adalah sebuah ontologi rekam medis yang dihasilkan dengan metode konversi database relasional ke dalam ontologi. Berdasarkan hasil uji konsistensi ontologi dengan metode OntoQA, didapatkan nilai Relationship Richness $(\mathrm{RR})=0,78$, yang artinya ontologi ini bersifat kaya informasi atau berragam dan lebih banyak relasi non-inheritance. Dan nilai Attribute Richness $(\mathrm{AR})=6,6$, yang artinya ontologi ini memiliki informasi yang banyak dengan rata-rata setiap class memiliki 6 attribute. Adapun nilai Inhertitance Richness (IR) =4,5, yang artinya ontologi ini memiliki pengetahuan yang umum, jika dibandingkan dengan ontologi terdahulu ada diantara PSM dan SWETO.

Dengan demikian, penelitian ini berhasil menyelesaikan permasalahan yang timbul akibat kesenjangan pendekatan penyusunan ontologi berdasarkan landasan hukum dengan tuntutan kemudahan mengimplementasikan ontologi ke dalam sebuah sistem.

Ontologi Rekam medis ini sudah memenuhi kepatuhan terhadap landasan hukum seputar rekam medis yang berlaku dan juga memiliki pendekatan database relational agar mudah diimplementasikan dalam sebuah semantic system untuk pengelolaan rekam medis.

\section{UCAPAN TERIMAKASIH}

Penulis mengucapkan terima kasih Politeknik Caltex Riau yang telah memberikan dukungan moril maupun materil dalam proses penulisan hasil penelitian ini.

\section{DAFTAR PUSTAKA}

[1] S. W. N. Nugraheni, “Aspek Hukum Rekam Medis Elektronik di RSUD Dr Moewardi,” Pros. Semin. Nas. Unimus, 2018.

[2] N. A. Samandari, W. Chandrawila S, and A. H. Rahim, "KEKUATAN PEMBUKTIAN REKAM MEDIS KONVENSIONAL DAN ELEKTRONIK," SOEPRA, 2017, doi: 10.24167/shk.v2i2.818.

[3] Kementrian Kesehatan Republik Indonesia, Peraturan Kementerian Kesehatan No. 269/2008 tentang Rekam Medis. 2008.

[4] F. Erawantini, E. Nugroho, G. Y. Sanjaya, and S. Hariyanto, "Rekam Medis Elektronik: Telaah Manfaat dalam Konteks Pelayanan Kesehatan Dasar," Fiki, 2013.

[5] Abdul Kadir, "Pengenalan Sistem Informasi Edisi Revisi," Edisi Revisi. 2014. 
[6] L. Yu and L. Yu, "OWL: Web Ontology Language," in A Developer's Guide to the Semantic Web, 2014.

[7] J. Hendler and T. Berners-Lee, "From the Semantic Web to social machines: A research challenge for AI on the World Wide Web," Artificial Intelligence. 2010, doi: 10.1016/j.artint.2009.11.010.

[8] M. R. A. Saf, P. I. Santosa, and S. S. Kusumawardani, "Perancangan Ontologi Rekam Medis di Indonesia berdasarkan Landasan Hukum yang Berlaku," J. Nas. Pendidik. Tek. Inform., 2015, doi: 10.23887/janapati.v4i1.9746.

[9] S. Tartir, I. B. Arpinar, and A. P. Sheth, "Ontological evaluation and validation," in Theory and Applications of Ontology: Computer Applications, 2010.

[10] T. S. Gunawan and G. M. Christianto, "Rekam Medis/Kesehatan Elektronik (RMKE): Integrasi Sistem Kesehatan,” J. Etika Kedokt. Indones., 2020, doi: 10.26880/jeki.v4i1.43.

[11] M. Saifullslam and M. Rokonuzzaman, "Adaptation of ATAM SM to Software Architectural Design Practices for Organically Growing Small Software Companies," no. Iccit, pp. 21-23, 2009.

[12] C. H. Liao, Y. F. Wu, and G. H. King, "Research on Learning OWL Ontology from Relational Database," in Journal of Physics: Conference Series, 2019, doi: 10.1088/17426596/1176/2/022031.

[13] N. Cahyono, E. Utami, and A. Amborowati, "Konseptualisasi Ontologi Iklan Website," J. Buana Inform., 2016, doi: 10.24002/jbi.v7i4.768.

[14] S. Tartir, I. Arpinar, M. Moore, A. Sheth, and B. Aleman-Meza, "OntoQA: Metric-Based Ontology Quality Analysis," in IEEE Workshop on Knowledge Acquisition from Distributed, Autonomous, Semantically Heterogeneous Data and Knowledge Sources, 2005, pp. 45-53, doi: 10.1.1.131.2087.

[15] M. R. A. Saf, "Pemodelan Ontologi untuk Sistem Informasi Proyek Akhir (SIMPOA) di Politeknik Caltex Riau," J. Siains, Teknol. dan Ind., vol. 13, no. 1, pp. 46-52, 2015, [Online]. Available: http://ejournal.uin-suska.ac.id/index.php/sitekin/article/view/1330/1256.

[16] R. Guha and R. McCool, "TAP: A Semantic Web platform," Computer Networks. 2003, doi: 10.1016/S1389-1286(03)00225-1.

[17] X. C. Tan, K. H. Yew, and T. J. Low, "Ontology design for process safety management," in 2012 International Conference on Computer and Information Science, ICCIS 2012 - A Conference of World Engineering, Science and Technology Congress, ESTCON 2012 Conference Proceedings, 2012, doi: 10.1109/ICCISci.2012.6297223.

[18] B. Aleman-Meza, C. Halaschek, A. Sheth, I. B. Arpinar, and G. Sannapareddy, "SWETO: Large-Scale Semantic Web Test-bed," in Proceedings, 16th International Conference on Software Engineering \& Knowledge Enginerring (SEKE2004), Workshop on Ontology in Action, Banff, Canada, June 21-24, 2004, 2004.

[19] C. J. Thomas, A. P. Sheth, and W. S. York, "Modular ontology design using canonical building blocks in the biochemistry domain," in Frontiers in Artificial Intelligence and Applications, 2006. 